\title{
Strani radnici u Hrvatskoj: porijeklo, status, orijentacije
}

DOI: $10.11567 /$ met.29.3.3

UDK: 331.556.44(497.5)

Prethodno priopćenje

Primljeno: 27.12.2013.

Prihvaćeno: 13.2.2014.

\section{Saša Božić}

Odjel za sociologiju, Sveučilište u Zadru, Zadar

sbozic@unizd.hr

\section{Boško Kuzmanović}

Odjel za sociologiju, Sveučilište u Zadru, Zadar

bkuzmano@unizd.hr

\section{Valerija Barada}

Odjel za sociologiju, Sveučilište u Zadru, Zadar vbarada@unizd.hr

\section{SAŽETAK}

Hrvatsku se u javnome diskursu doživljava prije svega kao emigracijsku, a ne imigracijsku zemlju, no trendovi mobilnosti radne snage u posljednjih desetak godina upućuju na zaključak da Hrvatska nije više isključivo emigracijska zemlja. Hrvatska sve više postaje zemlja radne imigracije, premda nije riječ o velikom broju (registriranih) radnika. Budući da nisu poznati podaci o porijeklu, statusu, kvaliteti života i orijentacijama stranih radnika u Hrvatskoj, ovo eksplorativno istraživanje bilo je usmjereno na rasvjetljavanje njihova socijalnog položaja. Istraživanje je utvrdilo osnovne demografske karakteristike stranih radnika, njihovo geografsko porijeklo, način i razloge dolaska i osnovne trendove u pogledu njihove socijalne isključenosti i diskriminacije te trajnosti migracijskoga procesa. Usto su dobiveni uvidi u društvene veze i kontakte stranih radnika u Hrvatskoj, kontakte s rođacima i prijateljima u drugim zemljama te životne planove i orijentaciju imigranata.

KLJUČNE RIJEČI: Hrvatska, imigranti, radna imigracija, socijalna isključenost, kvaliteta života, transnacionalne veze

\section{UVOD}

Iako se može tvrditi da se Hrvatsku u javnome diskursu doživljava prije svega kao emigracijsku, a ne imigracijsku zemlju, trendovi mobilnosti radne snage u posljednjih desetak godina upućuju na zaključak da Hrvatska 
nije više isključivo emigracijska zemlja. Hrvatska sve više postaje zemlja radne imigracije, premda nije riječ o velikom broju (registriranih) radnika. No ti su trendovi zanemarena tema među novinarima, političarima i društvenim znanstvenicima, pa ni znanstvena ni opća javnost nisu upoznate $\mathrm{s}$ fenomenom radne imigracije u Hrvatsku. Budući da nisu poznati podaci o porijeklu, statusu, kvaliteti života i orijentacijama stranih radnika u Hrvatskoj, ovo je istraživanje bilo usmjereno na rasvjetljavanje socijalnog položaja populacije stranih radnika u Hrvatskoj, na njihovu socijalnu, pravnu i ekonomsku integriranost u hrvatsko društvo, razinu kvalitete života, njihove orijentacije i planove. ${ }^{1}$ Takvo eksplorativno istraživanje posebno je važno za utvrđivanje svih važnih karakteristika rane faze imigracijskog procesa jer je vrlo vjerojatno da će se utvrđeni obrasci ponavljati u slučaju ponovnog razvoja industrijskih grana koje su privlačile dosadašnji tip radnih imigranata, posebice brodogradnje i građevinarstva. Istraživanje odgovara na nekoliko pitanja uobičajenih za istraživanja položaja, statusa i integraciju raznih društvenih grupa te daje prve informacije o migracijskim iskustvima najvažnijeg dijela populacije radnih migranata u Hrvatskoj.

Naime riječ je o pitanjima tko su strani radnici, odakle dolaze, kako žive, jesu li socijalno isključeni ili pak izloženi diskriminaciji i nasilju, kakve socijalne kontakte i veze ostvaruju u zemlji porijekla i u Hrvatskoj te, naposljetku, kakvi su im radni i životni planovi. Odgovor na pitanja »Tko su?« i »Odakle dolaze?« daje uvid u demografske karakteristike stranih radnika i njihovo geografsko porijeklo te način i razloge dolaska, što omogućuje utvrđivanje zastupljenosti različitih tipova radnih migranata u Hrvatskoj. Odgovorom na pitanje »Kako žive? « dobiva se uvid u uvjete života stranih radnika i mogući odgovor na pitanje jesu li, i u kojoj mjeri, izloženi socijalnoj isključenosti i diskriminaciji.

Koncept socijalne isključenosti široko se primjenjuje u istraživačkoj praksi, a u svojoj praksi javnih politika prihvatile su ga različite međunarodne institucije (poput Organizacije za ekonomsku suradnju i razvoj - OECD, Ujedinjenih naroda - UN i Međunarodne organizacije rada - ILO) i države (npr. Velika Britanija i Francuska). No i dalje je riječ o prijepornom konceptu o kojemu još nije postignut potpuni definicijski konsenzus (Šućur, 2004), premda se može utvrditi postojanje suglasnosti oko njegovih glavnih značajki, pa se socijalnu isključenost može odrediti kao »razmjerno trajnu, višestruko uvjetovanu i višedimenzionalnu depriviranost (prikraćenost) pojedinca «(Siromaštvo, nezaposlenost i socijalna isključenost, 2006: 26). Posri-

Provedbu istraživanja inicirala je i financirala zaklada Friedrich Ebert u Zagrebu u koordinaciji sa Savezom samostalnih sindikata Hrvatske. 
jedi je multidimenzionalan fenomen, unutar kojega se razlikuju tri sfere prikraćenosti: radna (nezaposlenost), financijska ili ekonomska (siromaštvo) te sociokulturna (društvena izolacija) (Maslić Seršić, Galić i Šverko, 2006; Siromaštvo, nezaposlenost i socijalna isključenost, 2006). Socijalna isključenost podrazumijeva deprivaciju pojedinca u sve tri navedene sfere.

Glavne razlike u postojećim istraživanjima socijalne isključenosti javljaju se prilikom definiranja pojedinih sfera, tj. određivanja prikladnih indikatora (Šućur, 2006). Za potrebe ovog istraživanja uvedeno je razlikovanje distribucijskog i relacijskog aspekta isključenosti (Bhalla i Lapeyre, 1995; Šućur, 2004), čime su objedinjene britanska i francuska tradicija u istraživanju socijalne isključenosti, koje su dosad bile odvojene. Distribucijska isključenost obuhvaća rad (nezaposlenost), obrazovanje, prihode, uvjete stanovanja i zdravlje, dok se relacijska tiče formalne društvene participacije i socijalnih kontakata, tj. izolacije. Takvo određenje obuhvaća sve tri osnovne sastavnice socijalne isključenosti na konceptualno i operacionalno jasan način. Dakle usvajanje koncepta socijalne isključenosti omogućuje cjeloviti uvid u uvjete života stranih radnika te usporedbu rezultata dobivenih ovim istraživanjem s raznim prethodnim studijama. Dodatna vrijednost i relevantnost ovog istraživanja leže $u$ činjenici da migranti pripadaju u skupine koje su posebno izložene riziku od socijalne isključenosti (Siromaštvo, nezaposlenost $i$ socijalna isključenost, 2006: 14).

S obzirom na navedeno ispitane su različite domene života stranih radnika: njihov pravni i socioekonomski status, uvjeti stanovanja, zdravlje, participacija u nevladinim organizacijama te socijalni kontakti, tj. izolacija. Nezaposlenost je bitna dimenzija socijalne isključenosti, no ona se u ovom istraživanju tretira na poseban način jer su svi ispitanici zaposleni u Hrvatskoj, zato što je rad ključni element njihove migracije. No postoji mogućnost da su došli raditi u Hrvatsku upravo zato što su bili izloženi radnoj isključenosti u zemlji porijekla, pa je ispitano u kolikoj je mjeri upravo ta nemogućnost pronalaska posla utjecala na njihovu odluku o dolasku. Restrukturiranje tvrtki i ekonomska kriza međutim mogu strane radnike pogoditi više od domaćih jer gubitkom posla gube i pravnu osnovu za boravak u Hrvatskoj, pa mogu biti suočeni s trajnijom isključenjem iz tržišta rada, gubitkom mjesta za stanovanje te potpunim isključenjem iz teritorija Republike Hrvatske. U kontekstu socijalne isključenosti na koncu je uvrštena i samoprocjena kvalitete života u Hrvatskoj, kako bi se dobio dodatni indikator subjektivnoga socioekonomskog statusa, odnosno eventualne subjektivne socioekonomske isključenosti. 
U istraživanju se ispituje i izloženost diskriminaciji i nasilju stranih radnika tijekom njihova boravka u Hrvatskoj. Riječ je o relevantnoj dimenziji iskustva radne migracije jer diskriminacija migranata nije sustavno istraživana. Premda se općenito može reći da su istraživanja socijalne isključenosti u nas malobrojna, a da su se postojeća obično bavila nezaposlenima, ipak se istraživački raspolaže referentnim okvirom za eventualne usporedbe s ovdje prikazanim rezultatima (Maslić Seršić, Galić i Šverko, 2006; Siromaštvo, nezaposlenost $i$ socijalna isključenost, 2006).

$\mathrm{Na}$ koncu, cjeloviti odgovor na pitanje »Kako žive? « dobiven je i uvidima u društvene veze i kontakte stranih radnika u Hrvatskoj te saznanjima o kontaktima s rođacima i prijateljima u drugim zemljama. Rasvjetljavanje fenomena radne imigracije završava prikazom životnih planova i orijentacija imigranata, posebice u vezi s njihovim ostankom u Hrvatskoj i useljavanjem drugih članova obitelji, odnosno preseljenjem u treće zemlje ili povratkom u mjesto i/ili zemlju porijekla. Suvremena istraživanja (Itzigsohn i Giorguli Saucedo, 2002; Landolt, 2001; Levitt, DeWind i Vertovec, 2003; Mazzucato, 2010) pokazuju da migranti aktivno grade i održavaju socijalne veze preko granica imigracijskih zemalja, stvaraju nove oblike socijalnih prostora koji se mogu protezati na nekoliko zemalja te često remigriraju u zemlju porijekla ili treće zemlje. Životi suvremenih migranata većinom ne odgovaraju slici koju o njima grade novinari, političari, pa i sami društveni znanstvenici. Trajniji boravak u nekome mjestu izvan granica zemlje porijekla još ne znači i da je osoba koju se označuje migrantom zauvijek odlučila ostati $\mathrm{u}$ tome mjestu, no ni da je potpuno sedentarna. Odlazak u treće zemlje, povratak u mjesto porijekla, a zatim i remigracija u prvo odredište, uz mogućnost međunarodne cirkulacije ili pendularne mobilnosti, opcije su koje prepoznaje i njima se koristi sve veći broj migranata. Usto se pretpostavke o prekidu socijalnih veza s mjestom porijekla, iskorjenjivanju i desocijalizaciji migranata sve rjeđe potvrđuju, a povijesna istraživanja tzv. migrantskog transnacionalizma pokazuju da takav tijek prelaska i prilagodbe uz napuštanje društvenih veza s mjestom porijekla nije postojao čak ni u prošlom i pretprošlom stoljeću (Foner, 1997). Zato je davanje uvida u transnacionalne veze migrantskih radnika danas obveza svakog istraživača migracija, a ne tek dodatna ilustracija migrantskih putova.

\section{METODE I POSTUPCI}

Zbog eksplorativnoga karaktera ovog istraživanja te ograničenih resursa i vremena provedeno je anketno istraživanje na prigodnom uzorku, a 
kao okvir uzorkovanja populacije stranih radnika uzeti su podaci o izdanim radnim dozvolama Ministarstva unutarnjih poslova za 2010. i posebno 2011. godinu, prije početka istraživanja na dan 28. lipnja 2011., kako bi se uzele u obzir tvrtke koje su ostale aktivne u uvjetima recesije, odnosno one čiji su radnici zatražili i kojima je odobreno produženje radne dozvole ${ }^{2}$. Gotovo polovina stranih radnika s radnom dozvolom zaposlena je u najvećim hrvatskim gradovima, a i veći dio ostatka nalazi se u široj okolici tih gradova. No zbog ograničenih sredstava i relativne geografske, ali i zaposleničke ${ }^{3}$ raspršenosti populacije podaci su prikupljeni na prigodnom uzroku od 61 ispitanika, i to u Zagrebu, Karlovcu i Rijeci.

Tablica 1. Broj stranih radnika s radnom dozvolom prema sektoru zaposlenja

Table 1. The number of foreign workers with work permits by sector of employment

\begin{tabular}{lcc}
\hline Sektor zaposlenja & $\mathbf{N}$ & $\mathbf{\%}$ \\
\hline Brodogradnja & 277 & 18,25 \\
\hline Poljoprivreda i ribarstvo & 36 & 2,37 \\
\hline Građevinarstvo & 1106 & 72,86 \\
\hline Industrija & 8 & 0,53 \\
\hline Promet i veze & 3 & 0,20 \\
\hline Trgovina & 1 & 0,07 \\
\hline Ugostiteljstvo i turizam & 71 & 4,68 \\
\hline Obrazovanje i znanost & 2 & 0,13 \\
\hline Zdravstvo & 8 & 0,53 \\
\hline Kultura & 5 & 0,33 \\
\hline Informatika & 1 & 0,07 \\
\hline Ukupno & $\mathbf{1 5 1 8}$ & $\mathbf{1 0 0 , 0}$ \\
\hline
\end{tabular}

Izvor: MUP, 28. lipnja 2011.

2 Usprkos recesiji MUP je do kraja godine izdao 566 novih radnih dozvola unutar kvota, a produžio je 5300 (Ministarstvo unutarnjih poslova, 31. prosinca 2011.).

3 Strani su radnici naime zaposleni kod 441 različitog poslodavca na području cijele Hrvatske. 
Iz tablice 1 razvidno je, a i očekivano, da je najviše stranih radnika u sektoru građevinarstva, što je slično iskustvima južnoeuropskih imigracijskih zemalja (vidi Gregurović, 2011: 67). Iznimno naporan, nesiguran i uglavnom slabo plaćen rad (u usporedbi s tercijarnim sektorom čak i u Hrvatskoj) koji često traži i spremnost na mobilnost ovisno o području rada tvrtke, uza stalnu izloženost vremenskim prilikama, nije posebno privlačan hrvatskim radnicima, čak ni unatoč trenutačnoj visokoj stopi nezaposlenosti ${ }^{4}$. Tijekom "građevinskog buma u u Hrvatskoj prošloga desetljeća postojao je i veći nedostatak radne snage, tako da su zabilježeni slučajevi ilegalne radne imigracije u području građevinarstva, čak i iz zemalja Europske unije. Isti razlozi za imigraciju stranih radnika mogu se pronaći i u sektorima ugostiteljstva i turizma. Sezonalan, nestalan i naporan posao koji tijekom ljetnih mjeseci može daleko nadmašiti uobičajenih osam sati dnevno uputio je poslodavce na strane radnike, posebice iz susjedne Bosne i Hercegovine, čije je poznavanje hrvatskog jezika zasigurno dodatni razlog upošljavanja ${ }^{5}$. U brodogradnji je međutim riječ o potrebi za posebnim tipom radnika koji su bili deficitarni, a čija je specijalizacija neophodna za izgradnju kompliciranih brodova. Hrvatski obrazovni sustav nije proizveo dovoljan broj radnika za te struke, što je poslodavce uputilo na specijalizirane rumunjske, a zatim i ukrajinske radnike. Naime nakon ulaska Rumunjske u Europsku uniju njihovim su radnicima atraktivnijima postala europska brodogradilišta, pa su se hrvatski poslodavci okrenuli sljedećemu dostupnom tržištu, ukrajinskome. Uz određeni broj visokospecijaliziranih radnika u brodogradnji je zaposlen i veliki broj radnika u tvrtkama kooperantima koje proizvode dijelove za koje nije neophodna posebna kvalifikacija u brodogradnji, pa valja pretpostaviti da je tu posrijedi veći broj manje kvalificiranih radnika.

Iz distribucije radnika s radnom dozvolom prema veličini tvrtke može se iščitati i sektorska raspodijeljenost stranih radnika u Hrvatskoj.

4 Stopa registrirane nezaposlenosti u Republici Hrvatskoj za studeni 2013. iznosila je 21,1\% (http://www.hzz.hr/default.aspx).

5 Valja primijetiti da je posljednjih godina zamjetna unutarnja sezonska migracija, kada radnici, odnosno radnice, prije svega iz Slavonije, odlaze na ljetne poslove u Dalmaciju i Istru. Ti su poslovi često rodno određeni jer obuhvaćaju poslove sobarica, pomoćnih radnica u kuhinji ili spremačica (Barada, 2013). 
Tablica 2. Distribucija stranih radnika s radnom dozvolom prema veličini tvrtke

Table 2. Distribution of foreign workers with work permits according to firm size

\begin{tabular}{ccccc}
\hline Razred & $\begin{array}{c}\text { Broj } \\
\text { radnika }\end{array}$ & $\begin{array}{c}\text { Udio } \\
\text { radnika (\%) }\end{array}$ & $\begin{array}{c}\text { Broj } \\
\text { poslodavaca }\end{array}$ & $\begin{array}{c}\text { Udio } \\
\text { poslodavaca } \\
\mathbf{( \% )}\end{array}$ \\
\hline 51 i više & 212 & 14,0 & 1 & 0,2 \\
\hline $30-50$ & 116 & 7,6 & 3 & 0,7 \\
\hline $20-29$ & 124 & 8,2 & 5 & 1,1 \\
\hline $10-19$ & 115 & 7,6 & 9 & 2,0 \\
\hline $5-9$ & 251 & 16,5 & 38 & 8,6 \\
\hline $3-4$ & 324 & 21,4 & 98 & 22,2 \\
\hline 2 & 178 & 11,7 & 89 & 44,9 \\
\hline 1 & 198 & 13,0 & 198 & $\mathbf{1 0 0 , 0}$ \\
\hline Ukupno & $\mathbf{1 5 1 8}$ & $\mathbf{1 0 0 , 0}$ & 441 & \\
\hline
\end{tabular}

Izvor: MUP, 28. lipnja 2011.

Najveći broj radnika radi kod poslodavaca koji upošljavaju tri do četiri radnika te kod onih koji upošljavaju pet do devet radnika. Oko desetine migranata radi u malim poduzećima s dva ili samo jednim zaposlenikom, dok se pojavljuje samo jedan veliki poslodavac koji angažira više od dvjesto stranih radnika. Najmanje radnika radi u srednje velikim poduzećima. Takva distribucija slijedi logiku sektora građevinarstva i brodogradnje, $\mathrm{u}$ kojima su zaposleni strani radnici. Naime, kako je već navedeno, ti sektori poznaju zapošljavanje većeg broja radnika, ali i kooperantski rad koji servisira veće naručitelje $\mathrm{u}$ brodogradnji i građevinarstvu.

Upitnik se sastojao od 120 čestica, a ispunjavali su ga anketari koji su bili upućeni da razgovor obave samo s ispitanicima, bez prisutnosti kolega ili poslodavaca, u prostoriji koja osigurava anonimnost i opuštenost. Iznimka su bili radnici koji ne znaju hrvatski jezik, kada je bila dopuštena prisutnost prevoditelja. Prilikom određivanja indikatora i njihove operacionalizacije primjenjivani su postojeći mjerni instrumenti uza stanovite prilagodbe i proširenja kako bi se unutar svih aspekata socijalne isključenosti dobili i subjektivni i objektivni pokazatelji (Šućur, 2004, 2006; Maslić Seršić, Galić i 
Šverko, 2006). U skladu s deskriptivnom naravi istraživanja, u obradi podataka upotrijebljena je univarijatna statistička analiza.

\section{REZULTATI ISTRAŽIVANJA}

Prikaz rezultata istraživanja slijedi upitnik, pa se ovdje redom prikazuju demografska obilježja uzorka uz porijeklo i razloge dolaska u Hrvatsku. Obrađuju se i pravni te socioekonomski status stranih radnika te uvjeti stanovanja, samoprocjena kvalitete života i zdravlja. Osim toga u rezultate istraživanja uključena su razmatranja o socijalnoj isključenosti i doživljenim slučajevima diskriminacije, prije svega na radnome mjestu u Hrvatskoj. Završno se prikazuju socijalne veze ispitanika u transnacionalnom kontekstu te ispituju planovi u smislu daljnje migracije ili ujedinjenja obitelji u Hrvatskoj.

\section{Demografska obilježja uzorka}

Kako je istraživanje obuhvatilo šezdeset muškaraca i samo jednu ženu, može se ustvrditi da su žene podzastupljene u ovom istraživanju. Konkretni podaci o rodnom sastavu populacije nisu dostupni, pa se ne može s potpunom sigurnošću zaključivati o eventualnoj rodnoj pristranosti uzorka. No s obzirom na zastupljenost stranih radnika po sektoru zaposlenja (vidi tablicu 1), iz koje je razvidno da su zaposleni najviše u građevinarstvu i brodogradnji, može se pretpostaviti da je i cijela populacija stranih radnika $\mathrm{s}$ radnom dozvolom dominantno muška. Naime s obzirom na tip poslova koje obavljaju strani radnici u Hrvatskoj vrlo je vjerojatno da ovi podaci ne odstupaju previše od stvarne zastupljenosti muške populacije u ukupnoj populaciji stranih radnika ${ }^{6}$.

Uvidom u dobnu distribuciju ispitanika u uzorku pokazuje se da je oko dvije trećine stranih radnika u dobi od trideset do pedeset godina. Petina ispitanika u dvadesetim je godinama, a manje od desetine ima više od pedeset godina. Dakle uglavnom je riječ o muškarcima u najproduktivnijoj životnoj dobi.

6 Poslovi koji su na raspolaganju migranticama obično su u domeni kućanskog rada i skrbi za ovisne članove obitelji, bilo da je riječ o djeci, bolesnima ili starijima, a često je posrijedi nelegalna, odnosno neevidentirana migracija (Morokvasic, 2004; Lutz, 2002; Hess i Lenz, 2001). Dio radne migracije mladih žena prikriven je tzv. au pair-poslovima, koji su često evidentirani kroz studentske vize za učenje stranih jezika u odredišnim zemljama (Hess, 2002). Slična se strategija pojavljuje kod mladih žena iz Bosne i Hercegovine koje imaju hrvatsko državljanstvo, a u Hrvatskoj se ili školuju u visokoškolskim institucijama ili registriraju na Hrvatski zavod za zapošljavanje kao domicilno stanovništvo, pa nisu registrirane kao strani radnici (Barada, 2013). 
Tablica 3. Ispitanici prema dobi

Table 3. Respondents by age

\begin{tabular}{lcc}
\hline Dob & $\mathbf{N}$ & $\mathbf{\%}$ \\
\hline $20-29$ & 13 & 21,3 \\
\hline $30-39$ & 26 & 42,6 \\
\hline $40-49$ & 17 & 27,9 \\
\hline $50-59$ & 5 & 8,2 \\
\hline Ukupno & $\mathbf{6 1}$ & $\mathbf{1 0 0 , 0}$ \\
\hline
\end{tabular}

Dvije su trećine ispitanika u braku, četvrtina su samci, a jedan je razveden. Od ukupnog broja ispitanika njih četrdeset ima djecu. Petnaest ispitanika ima troje djece, trinaest dvoje, jedanaest jedno i jedan ispitanik četvero djece. Osim ukupnog broja djece, iz pregleda materijalno ovisne djece jasno je da gotovo svi ispitanici (njih 39) imaju djecu za koju se moraju skrbiti. Ti podaci upućuju na zaključak da su među stranim radnicima najzastupljeniji hranitelji obitelji koji doznakama uzdržavaju svoje obitelji. Visoki životni troškovi u Hrvatskoj i relativno niske plaće ne dopuštaju preseljenje obitelji, barem ne u kratkom roku, a doznake, makar i niže svote, vjerojatno su velika pomoć obiteljima. Takva obiteljska raspodjela slijedi koncept tzv. muškoga hranitelja (engl. male breadwinner model), prema kojemu muškarci zarađuju obiteljski dohodak kojim se financijski skrbe za obitelj, dok žene uglavnom obavljaju kućanske poslove i emocionalno se skrbe za obitelj ${ }^{7}$ (Crompton, 1999). Kad je riječ o stranim radnicima, posrijedi su pojačana rodna podjela posla i dodatno definirane rodne uloge, jer muškarci odlaze iz doma te sve vrijeme svoga izbivanja posvećuju zaradi koju šalju obitelji.

Prema raspodjeli stupnja obrazovanja (tablica 4) riječ je o relativno slabije obrazovanoj populaciji u usporedbi s ukupnom populacijom Hrvatske, ali i zemalja iz kojih dolaze. Naime najveći dio ispitanika, njih 57,4\%, završilo je srednju školu, više od trećine (36\%) ima završenu tek osnovnu školu, dok svega 6,6\% ima završenu višu školu ili fakultet. No gledajući ukupnu

7 Kod migrantskih radnika, čak i kada je žena zaposlena, uloga hranitelja obitelji ostaje dominantnom upravo zbog izmještenosti muškarca i ovisnosti obitelji o tom prihodu. Ni kad oba partnera rade, u opisanim se slučajevima nikako ne može govoriti o obiteljima s dvostrukim karijerama (Ellingsaeter, 1999).

8 U Hrvatskoj 27,4\% stanovnika starijih od devetnaest godina ima završenu osnovnu školu, $54,8 \%$ stanovništva starijeg od devetnaest godina ima završenu srednju školu, a 17,6\% visoko obrazovanje (www.dzs.hr). 
populaciju stranih radnika, posrijedi su obrazovani radnici koji su ili stručno obrazovani za posao koji obavljaju ili obavljaju posao ispod razine svoga obrazovanja. Samo se za radnike s osnovnom školom može zaključiti kako je riječ o nekvalificiranim radnicima, koji su međutim neophodni kao pomoćni radnici u građevinarstvu i nekim drugim djelatnostima. Slabije obrazovanje često se ističe kao glavni uzrok nezaposlenosti i isključenosti (Siromaštvo, nezaposlenost i socijalna isključenost, 2006), pa se može zaključiti kako je podobrazovana skupina stranih radnika ranjiva te izložena riziku od isključenosti.

Tablica 4. Stupanj obrazovanja ispitanika

Table 4. The respondents' level of education

\begin{tabular}{lcc}
\hline Stupanj obrazovanja & N & \% \\
\hline Osnovna škola & 22 & 36,0 \\
\hline Srednja škola & 35 & 57,4 \\
\hline Viša škola ili fakultet & 4 & 6,6 \\
\hline Ukupno & $\mathbf{6 1}$ & $\mathbf{1 0 0 , 0}$ \\
\hline
\end{tabular}

U prilog argumentu izloženosti isključenosti ide i raspodjela zanimanja navedena u tablici 5, s tek ukupno tri ispitanika koja zauzimaju rukovodeća mjesta, tri ispitanika umjetničkih zanimanja (ukupno 9,8\%) te zamjetnih 13\% nekvalificiranih radnika. Najveći broj, odnosno dvije trećine uzorka, upravo je u kategoriji kvalificiranih radnika, što je u skladu sa sektorima koji dominantno zapošljavaju strane radnike s radnom dozvolom.

Tablica 5. Ispitanici prema zanimanju

Table 5. Respondents by occupation

\begin{tabular}{lcc}
\hline Zanimanje & $\mathbf{N}$ & $\mathbf{\%}$ \\
\hline Viši rukovoditelj/stručnjak & 1 & 1,6 \\
\hline Niži/srednji rukovoditelj/poslovođa & 2 & 3,3 \\
\hline Kvalificirani radnik & 47 & 77,1 \\
\hline Nekvalificirani radnik & 8 & 13,1 \\
\hline Umjetnik & 3 & 4,9 \\
\hline Ukupno & $\mathbf{6 1}$ & $\mathbf{1 0 0 , 0}$ \\
\hline
\end{tabular}




\section{Porijeklo i dolazak u Hrvatsku}

Tablica 6 pokazuje da su gotovo svi ispitanici u uzorku porijeklom iz Bosne i Hercegovine, što može upućivati na geografsku pristranost uzorka ${ }^{9}$. Iako ni u ovom slučaju nisu poznati populacijski podaci, prema podacima MUP-a iz 2011. može se pretpostaviti da bi i u slučajnome reprezentativnom uzorku ta geografska skupina predstavljala većinu. Ispitanici su uglavnom gradskog i prigradskog porijekla (ukupno 71,7\% uzorka), ali ih zamjetni broj, oko trećine uzorka $(28 \%)$, dolazi sa sela. Dominantna zemlja porijekla, Bosna i Hercegovina, odnosno njezina geografska, jezična i kulturna blizina Hrvatskoj, u izravnoj je vezi s prezastupljenošću stranih radnika tog porijekla. U kombinaciji s drugim čimbenicima, poput ekonomske situacije u Bosni i Hercegovini, koja je nepovoljnija nego u Hrvatskoj, ona se još uvijek nudi kao povoljno odredište za kvalificirane bosanske radnike koji nemaju hrvatsko državljanstvo, a već imaju obitelji. Vezanost uz sedentarnu obitelj s ovisnom djecom zahtijeva relativnu geografsku blizinu, koja, uz veću mobilnost i češće posjete, omogućuje fizičku prisutnost u obitelji, primjerice vikendima. Tako u Hrvatsku rjeđe dolaze neoženjeni migranti i neudane migrantice iz Bosne i Hercegovine, jer kako nisu geografski vezani uz obitelj, vrlo vjerojatno mogu pokušati pronaći bolje plaćen posao i osnovati obitelj u udaljenijim odredištima drugdje u svijetu, pogotovo ako su bolje obrazovani.

Tablica 6. Zemlja porijekla ispitanika

Table 6. The respondents' country of origin

\begin{tabular}{lcc}
\hline Zemlja porijekla & $\mathbf{N}$ & $\mathbf{\%}$ \\
\hline Austrija & 1 & 1,6 \\
\hline Bosna i Hercegovina & 57 & 93,4 \\
\hline Makedonija & 1 & 1,6 \\
\hline Moldavija & 1 & 1,6 \\
\hline Rumunjska & 1 & 1,6 \\
\hline Ukupno & $\mathbf{6 1}$ & $\mathbf{1 0 0 , 0}$ \\
\hline
\end{tabular}

9 Valja napomenuti da taj trend imigracije iz BiH u Hrvatsku može predstavljati nastavak tradicionalnih tadašnjih unutarnjih migracija na području bivše Jugoslavije (Mežnarić, 1991). 
Podaci o godini dolaska ispitanika u Hrvatsku pokazuju da ih je najveći dio stigao između 2007. i 2009., a nešto više od trećine i prethodno je boravilo i/ili radilo u Hrvatskoj. Taj je nalaz u skladu sa studijama (npr. Fassmann i Hintermann, 1997) koje upućuju da je iskustvo boravka i rada u određenom odredištu vrlo važan razlog ponovnog odabira tog mjesta i/ili zemlje. Drugi razlog koncentriranja odgovora ispitanika u navedenom razdoblju može se tražiti u činjenici da je određeni broj stranih radnika zatražio i vjerojatno dobio stalnu radnu dozvolu nakon pet godina kontinuiranog boravka u Hrvatskoj pa posljedično potražio i pronašao drugi, bolje plaćeni posao.

Tablica 7. Ispitanici prema godini dolaska u Hrvatsku

Table 7. Respondents by year of arrival in Croatia

\begin{tabular}{lcc}
\hline Godina dolaska & $\mathbf{N}$ & $\mathbf{\%}$ \\
\hline 1979. & 1 & 1,6 \\
\hline 1999. & 1 & 1,6 \\
\hline 2001. & 1 & 1,6 \\
\hline 2003. & 2 & 3,3 \\
\hline 2004. & 1 & 1,6 \\
\hline 2007. & 7 & 11,5 \\
\hline 2008. & 33 & 54,1 \\
\hline 2009. & 14 & 23,0 \\
\hline 2010. & 1 & 1,6 \\
\hline Ukupno & 61 & 100,0 \\
\hline
\end{tabular}

Zanimljivo je da vrlo mali broj ispitanika (njih osam) nije imao unaprijed poznato radno mjesto prilikom dolaska u Hrvatsku, dok je velika većina, njih 53, imala ugovoreno radno mjesto. Osim toga gotovo $61 \%$ ispitanika pronašlo je radna mjesta putem agencije, a 39\% samostalno.

Razlozi korištenja uslugama agencija za zapošljavanje u Hrvatskoj mogu se objasniti na nekoliko načina. Prije svega, takva praksa može upućivati na slabiju umreženost stranih radnika s hrvatskim državljanima te bosanskim useljenicima iz ranijih faza useljavanja i rada bosanskih radnika u Hrvatskoj, posebice šezdesetih godina dvadesetog stoljeća (Kuti, Gregurović i Božić, 2013). Može upućivati i na to da prijatelji i rođaci koji se već nala- 
ze u Hrvatskoj ne mogu pomoći pri nalaženju posla. Isto tako, postojanje i aktivnost agencija upućuju na potrebu hrvatskih poslodavaca da pronađu prikladnu radnu snagu za nepopunjena mjesta u Hrvatskoj regrutiranjem radnika iz Bosne i Hercegovine. Organiziranim regrutiranjem radne snage poslodavcima se smanjuju troškovi traženja radnika, ali se i samim radnicima olakšava dobivanje radnih dozvola i useljavanje.

Razlozi dolaska na rad u Hrvatsku ispitivani su na dva načina: prvo su sudionici istraživanja procjenjivali važnost petnaest različitih razloga na trostupanjskoj skali, a zatim navodili jedan ili dva najvažnija razloga za donošenje odluke o odlasku. Takav način ispitivanja razloga odabira rada u Hrvatskoj temelji se na klasičnome povlačno-potisnome modelu, koji je primijenjen u modificiranom obliku u suvremenim istraživanjima migracijskog potencijala (Fassmann i Hinterman, 1997; Božić i Burić, 2005).

Kod procjena, čije su raspodjele navedene u tablici 8, ispitanici su kao najvažnije razloge dolaska u najvećem broju isticali bolje uvjete rada, veću mogućnost zarade i nemogućnost pronalaska posla u vlastitoj zemlji te $\mathrm{u}$ nešto manjoj mjeri geografsku blizinu i relativnu lakoću dobivanja radne dozvole. No kad se izdvoje jedan ili dva presudna razloga iz te i sljedeće tablice, postaje jasno da je veća mogućnost zarade glavni, velikim dijelom i jedini bitni razlog dolaska. Nakon toga ističe se geografska blizina, koju je spomenulo nešto više od trećine ispitanika, a nemogućnost pronalaska posla i bolje uvjete rada, koje su prethodno visoko ocijenili, spomenulo je ukupno trinaest ispitanika.

Tablica 8. Razlozi za rad u Hrvatskoj

Table 8. Reasons for working in Croatia

\begin{tabular}{lcc|cc|cc}
\hline & \multicolumn{2}{c|}{ Nevažno } & \multicolumn{2}{c|}{$\begin{array}{c}\text { Donekle } \\
\text { važno }\end{array}$} & \multicolumn{2}{c}{ Jako važno } \\
\cline { 2 - 8 } Razlozi za rad u Hrvatskoj & $\mathbf{N}$ & \% & N & $\%$ & N & \% \\
\hline $\begin{array}{l}\text { U Hrvatskoj imam veće } \\
\text { mogućnosti za bolju zaradu. }\end{array}$ & 2 & 3,3 & 22 & 36,1 & 37 & 60,6 \\
\hline U Hrvatskoj su bolji uvjeti rada. & 2 & 3,3 & 16 & 26,2 & 43 & 70,5 \\
\hline $\begin{array}{l}\text { Nisam u svojoj zemlji mogao } \\
\text { pronaći nikakav posao. }\end{array}$ & 9 & 15 & 12 & 20 & 39 & 65 \\
\hline $\begin{array}{l}\text { Nisam u svojoj zemlji mogao } \\
\text { pronaći posao u struci. }\end{array}$ & 11 & 19 & 11 & 19 & 36 & 62 \\
\hline $\begin{array}{l}\text { Mogućnosti za napredovanje na } \\
\text { poslu u Hrvatskoj su bolje. }\end{array}$ & 13 & 22,4 & 26 & 44,8 & 19 & 32,8 \\
\hline
\end{tabular}




\begin{tabular}{|c|c|c|c|c|c|c|}
\hline \multirow{2}{*}{ Razlozi za rad u Hrvatskoj } & \multicolumn{2}{|c|}{ Nevažno } & \multicolumn{2}{|c|}{$\begin{array}{l}\text { Donekle } \\
\text { važno }\end{array}$} & \multicolumn{2}{|c|}{ Jako važno } \\
\hline & $\mathbf{N}$ & $\%$ & $\mathbf{N}$ & $\%$ & $\mathbf{N}$ & $\%$ \\
\hline $\begin{array}{l}\text { Politička situacija u Hrvatskoj je } \\
\text { bolja. }\end{array}$ & 41 & 69,5 & 10 & 16,9 & 8 & 13,6 \\
\hline $\begin{array}{l}\text { Želim doživjeti i upoznati nešto } \\
\text { novo. Znatiželjan/na sam. }\end{array}$ & 36 & 61 & 12 & 20,3 & 11 & 18,6 \\
\hline $\begin{array}{l}\text { Ekološki problemi, zagađenje u } \\
\text { sredini u kojoj sam živio. }\end{array}$ & 58 & 96,7 & 1 & 1,7 & 1 & 1,7 \\
\hline Zbog loših obiteljskih odnosa. & 59 & 98,3 & 1 & 1,7 & & \\
\hline $\begin{array}{l}\text { Kao pripadnik nacionalne manjine } \\
\text { osjećao sam se zakinut. }\end{array}$ & 59 & 98,3 & & & 1 & 1,7 \\
\hline $\begin{array}{l}\text { Prijatelji ili poznanici već žive u } \\
\text { Hrvatskoj. }\end{array}$ & 45 & 76,3 & 10 & 16,9 & 4 & 6,8 \\
\hline Zbog geografske blizine. & 11 & 18 & 18 & 29,5 & 32 & 52,5 \\
\hline $\begin{array}{l}\text { Pripadnici obitelji ili rođaci već } \\
\text { žive u Hrvatskoj. }\end{array}$ & 49 & 81,7 & 8 & 13,3 & 3 & 5 \\
\hline $\begin{array}{l}\text { Već sam boravio, radio u } \\
\text { Hrvatskoj. }\end{array}$ & 40 & 65,6 & 16 & 26,2 & 5 & 8,2 \\
\hline $\begin{array}{l}\text { U Hrvatskoj je jednostavnije dobiti } \\
\text { radnu dozvolu nego drugdje. }\end{array}$ & 14 & 23,3 & 18 & 30 & 28 & 46,7 \\
\hline
\end{tabular}

Tablica 9. Sumarni pregled razloga za rad u Hrvatskoj

Table 9. Summary of reasons for working in Croatia

\begin{tabular}{lc}
\hline Broj ispitanika & 46 \\
\hline Broj odgovora & 63 \\
\hline Veća mogućnost zarade. & $54 \%$ \\
\hline Geografska blizina. & $35 \%$ \\
\hline Jednostavnije je dobiti radnu dozvolu nego drugdje. & $15 \%$ \\
\hline Nemogućnost pronalaska posla u svojoj zemlji. & $13 \%$ \\
\hline Bolji uvjeti rada. & $11 \%$ \\
\hline Bolje mogućnosti napredovanja. & $2 \%$ \\
\hline
\end{tabular}




\begin{tabular}{ll}
\hline Znatiželja/želja da se doživi nešto novo. & $2 \%$ \\
\hline Prijatelji ili poznanici već rade u RH. & $2 \%$ \\
\hline Prethodni boravak/rad u RH. & $2 \%$ \\
\hline
\end{tabular}

Čini se da, iako je većina ispitanika bila izložena nezaposlenosti u zemlji porijekla, manja mogućnost zaposlenja igra manju ulogu od razlike u visini mogućih prihoda. Bolja zarada presudni je privlačni faktor. Geografska blizina zemlje porijekla većine ispitanika upućuje da je mogućnost održavanja lakšega kontakta s obitelji bila vjerojatno važna prilikom donošenja odluke o dolasku upravo u Hrvatsku.

\section{Pravni status stranih radnika u Hrvatskoj}

Od 57 ispitanika koji su odgovorili na pitanje o radnoj dozvoli većina (53 ili 93\%) ima radnu dozvolu koja traje samo godinu dana, dvoje ih ima na rok od godinu i pol te samo dvoje ima trajne radne dozvole. Kada se ta činjenica razmotri s podacima o učestalosti obnavljanja dozvole (tablica 10), čini se da gotovo svi ispitanici svake godine obnavljaju radnu dozvolu. Naime 46 ispitanika produživalo je radnu dozvolu dva ili tri puta, a budući da se trajna dobiva tek nakon pet godina boravka ${ }^{10}$, može se zaključiti da je u ovdje istraživanom uzorku riječ o »novim « migrantima, odnosno da je većina stranih radnika došla u Hrvatsku prije tri, četiri godine.

Tablica 10. Broj produživanja radne dozvole

Table 10. The number of work permit extensions

\begin{tabular}{ccc}
\hline Broj produživanja radne dozvole & $\mathbf{N}$ & $\mathbf{\%}$ \\
\hline 2 & 8 & 13,8 \\
\hline 3 & 25 & 43,1 \\
\hline 4 & 21 & 36,2 \\
\hline 5 & 3 & 5,2 \\
\hline 10 & 1 & 1,7 \\
\hline Ukupno & $\mathbf{5 8}$ & $\mathbf{1 0 0 , 0}$ \\
\hline
\end{tabular}

10 Hrvatski Zakon o strancima koji je bio na snazi u vrijeme istraživanja, bez izmjena i dopuna, omogućuje stjecanje trajnog boravka tek nakon pet uzastopnih godina rada, boravka i plaćanja doprinosâ (http://narodne-novine.nn.hr/clanci/sluzbeni/2011_11_130_2600.html). 
Za razliku od radne dozvole boravišnu dozvolu nemaju svi ispitanici. Naime pet ispitanika nema dozvolu boravka (tablica 11). Osim toga među većinom koja ima boravišnu dozvolu tek je u tri slučaja riječ o stalnoj dozvoli, što može potvrđivati kratkotrajni boravak u Hrvatskoj. Također može upućivati na već spomenutu pretpostavku o traženju drugih poslova nakon dobivanja trajne dozvole ili pak na mogućnost povratka u zemlju porijekla u slučaju neproduživanja dozvole. Opisani pravni uvjeti života i rada nisu povoljni za stalni boravak i konačno useljenje u Hrvatsku. U kombinaciji s planovima ispitanika (vidi niže) može se zaključiti da je kod stranih radnika, a posebice onih iz Bosne i Hercegovine, vjerojatnije riječ o ljudima kojima je boravak u Hrvatskoj strategija preživljavanja i uzdržavanja obitelji, a tek onda eventualni planirani korak za stalni boravak u smjeru konačnog preseljenja u Hrvatsku.

Tablica 11. Posjedovanje boravišne dozvole

Table 11. Owning a residence permit

\begin{tabular}{lcccccc}
\hline & \multicolumn{2}{c}{$\mathbf{N E}$} & \multicolumn{2}{c}{ DA } & \multirow{2}{*}{ Ukupno } \\
\cline { 2 - 5 } & $\mathbf{N}$ & $\mathbf{\%}$ & $\mathbf{N}$ & $\%$ & $\mathbf{N}$ \\
\hline Imate li boravišnu dozvolu? & 5 & 8,2 & 56 & 91,8 & 61 \\
\hline Imate li stalnu boravišnu dozvolu? & 58 & 95,1 & 3 & 4,9 & 61 \\
\hline
\end{tabular}

Rezultati istraživanja pokazuju kako nitko od ispitanika nije u braku s hrvatskim državljaninom/državljankom te da samo jedan ima roditelja s hrvatskim državljanstvom. Osim toga samo ih troje boravi u Hrvatskoj s članovima obitelji i u sva je tri slučaja riječ o bratu ili bratiću, iako je većina ispitanika vjenčana i ima materijalno ovisnu djecu. Taj podatak dodatno osnažuje pretpostavku da je kod stranih radnika u Hrvatskoj riječ o ranoj fazi imigracije, kada migranti pioniri, uglavnom muškarci hranitelji obitelji, u prvoj fazi imigracije pokušavaju osigurati egzistenciju i uvjete za eventualno buduće useljenje članova obitelji, pri čemu ne zanemaruju ni druge opcije, daljnje migracije ili povratka. Takav način strateškog ponašanja smanjuje rizik za cijelu obitelj, pogotovo kada materijalni uvjeti i pravna sigurnost nisu zajamčeni. Doduše istraživanjem je utvrđeno da svi radnici imaju zdravstveno i mirovinsko osiguranje, što je uz posjedovanje radne dozvole solidna pravna osnova boravka. Ipak, s obzirom na tip i trajanje tih dozvola još je uvijek posrijedi nedovoljno stabilna za doseljenje obitelji. Pravo 
spajanja obitelji široko je prihvaćeno pravo, pogotovo u zakonodavstvima zemalja Europske unije, pa tako i hrvatski Zakon o strancima omogućuje boravak na temelju prava spajanja obitelji ${ }^{11}$. Zato bi se moglo pretpostaviti da će strani radnici u Hrvatskoj s vremenom, nakon ekonomskog i pravnog osiguranja svoje egzistencije, pokušati iskoristiti to pravo te da će od stranih radnika postajati useljenici.

Na koncu, iz tablice 12 može se vidjeti da je polovina ispitanika bila upoznata s radnim i socijalnim pravima prije dolaska u Hrvatsku. Nakon dolaska taj se udio penje i na četiri petine uzorka, no još uvijek preostaje dvadesetak posto ispitanika koji ni nakon dolaska nisu bili upoznati sa svojim radnim i socijalnim pravima.

Tablica 12. Informiranost o radnim pravima

Table 12. Being informed about labour rights

\begin{tabular}{lccccc}
\hline & \multicolumn{3}{c}{ NE } & \multicolumn{3}{c}{ DA } & \multirow{2}{*}{ Ukupno N } \\
\cline { 2 - 5 } & $\mathbf{N}$ & $\mathbf{\%}$ & $\mathbf{N}$ & $\mathbf{\%}$ & \\
\hline $\begin{array}{l}\text { Jeste li bili upoznati s radnim i } \\
\begin{array}{l}\text { socijalnim pravima u Hrvatskoj } \\
\text { prije dolaska ovamo? }\end{array}\end{array}$ & 31 & 50,8 & 30 & 49,2 & 61 \\
\hline $\begin{array}{l}\text { Jeste li se upoznali s njima po } \\
\text { dolasku u Hrvatsku? }\end{array}$ & 13 & 21,3 & 48 & 78,7 & 61 \\
\hline
\end{tabular}

\section{Socioekonomski status, uvjeti stanovanja, kvaliteta života i zdravlje}

Socioekonomski status prije svega je iščitavan kroz problematiku redovitog i legalnog isplaćivanja plaća. Tako je utvrđeno da svi ispitanici primaju plaću svaki mjesec, uglavnom u cijelosti na bankovni račun, njih 51 ili $83,6 \%$, dok je svega deset ili $16,4 \%$ ispitanika isplaćivano na druge načine ili »na ruke«.

Najmanji prihod koji su ispitanici naveli u istraživanju iznosi 2.100,00 HRK, a najveći 7.000,00 HRK. Medijan za negrupirane podatke iznosi 3.550,00 HRK, a aritmetička sredina 3.790,00 HRK (uza standardnu devija-

11 Vidi Zakon o strancima (http://narodne-novine.nn.hr/clanci/sluzbeni/2011_11_130_2600. html), članak 56, koji omogućuje spajanje obitelji strancima s privremenim i stalnim boravkom u Republici Hrvatskoj, čak i kada stranac živi i u izvanbračnoj zajednici. Na dan 31.12.2011. dozvolu privremenog boravka u RH sa svrhom spajanja obitelji ostvarilo 3434 državljana $\mathrm{BiH}$ dok je privremeni boravak u svrhu rada ostvarilo 3829 državljana $\mathrm{BiH}$ (Izvor: MUP, 2012). 
ciju od 975,00 HRK). Grupirani se podaci mogu vidjeti u tablici 13. Usporedi li se uzorak u ovom istraživanju s recentnim podacima za opću populaciju u Hrvatskoj (Ostroški, 2011), prihodi su stranih radnika niži, što rezultira njihovim relativno niskim ekonomskim statusom. Naime prosječna primanja istraživanih stranih radnika izrazito su niža od hrvatskog prosjeka u 2011., koji je iznosio 5.343,00 HRK. Prema podacima iz spomenute tablice, samo 13\% ispitanika ima plaću koja je blizu ili iznad hrvatskoga prosjeka, odnosno primanja iznad 5.000,00 HRK. Sagledaju li se primanja ispitanika u odnosu na prag siromaštva, koji je za 2009. iznosio 26.703,00 HRK za samačka kućanstva, a 56.076,00 HRK za četveročlanu obitelj, ponovno se uočava ekonomska ugroženost ispitanika, a naročito onih s obitelji, premda valja uzeti u obzir činjenicu da su obitelji ispitanika u zemlji porijekla (gdje prevladava $\mathrm{BiH}$ ), pa bi primanja na razini kućanstava trebalo sagledati s obzirom na prosječne prihode i prag siromaštva u zemljama porijekla. Može se ustvrditi da nakon slanja dijela plaće obitelji strani radnici u Hrvatskoj žive ispod praga siromaštva. Time oni doslovno žive koncept hranitelja obitelji (Crompton, 1999) jer većinu novca šalju kući i tako se skrbe za obitelj (vidi niže), a samo dio novca zadržavaju za svoje preživljavanje.

Tablica 13. Iznos osobnoga mjesečnog prihoda

Table 13. The amount of personal monthly income

\begin{tabular}{lcc}
\hline & $\mathbf{N}$ & $\mathbf{\%}$ \\
\hline 2.000,00 HRK $-2.999,00$ HRK & 8 & 14,8 \\
\hline $3.000,00$ HRK $-3.999,00$ HRK & 24 & 44,4 \\
\hline $4.000,00$ HRK $-4.999,00$ HRK & 15 & 27,8 \\
\hline $5.000,00$ HRK $-5.999,00$ HRK & 5 & 9,3 \\
\hline 6.000,00 HRK - 7.000,00 HRK & 2 & 3,7 \\
\hline Ukupno & $\mathbf{5 4}$ & $\mathbf{1 0 0 , 0}$ \\
\hline
\end{tabular}

No subjektivna procjena financijske situacije ispitanika daje pozitivniju sliku od objektivnih pokazatelja, jer najveći dio njih kaže kako uopće nije imao financijskih problema u proteklih mjesec dana (tablica 14). Taj podatak može odražavati činjenicu da su u zemljama porijekla plaće još niže, a posao se pronalazi rjeđe nego u Hrvatskoj, pa u usporedbi sa svojim zemljama porijekla ispitanici ne smatraju da imaju financijskih poteškoća. Ipak, 
gotovo četvrtina kaže da ima financijske poteškoće povremeno, dok ih značajnih petnaest posto ima gotovo stalno, što upućuje da su strani radnici u Hrvatskoj u vrlo ranjivu financijskom položaju.

Tablica 14. Učestalost financijskih poteškoća u proteklih mjesec dana Table 14. The frequency of financial problems in the last month

\begin{tabular}{lcc}
\hline & N & \% \\
\hline Uopće nisam imao & 24 & 40,7 \\
\hline Rijetko & 10 & 16,9 \\
\hline Povremeno & 14 & 23,7 \\
\hline Često & 2 & 3,4 \\
\hline Gotovo stalno & 9 & 15,3 \\
\hline Ukupno & $\mathbf{5 9}$ & $\mathbf{1 0 0 , 0}$ \\
\hline
\end{tabular}

U tablici 15 naveden je način na koji su smješteni strani radnici. Gotovo svi ispitanici žive kao podstanari, pri čemu je velikoj većini smještaj osigurao poslodavac. Troškovi stanarine relativno su mali, pa najmanja zabilježena stanarina iznosi 200,00 HRK, a najveća 2.500,00 HRK, pri čemu je AS 527 (SD = 443). Oblik kolektivnog smještaja potvrđuje da je riječ o sezonskim migracijama ili pak o ranim fazama imigracije, kada aranžman između poslodavca i stranog radnika uključuje relativno niske plaće s jedne strane, koje se s druge strane kompenziraju relativno niskim troškovima kolektivnog smještaja. Pokušaj osamostaljenja i dovođenja obitelji u takvim je uvjetima vrlo riskantan potez koji se teško možr očekivati u uvjetima radnotržišnih fluktuacija i restriktivnog zakonodavstva. Premda se dugoročno, nakon pravnog i radnog osamostaljenja, strani radnici mogu pretvoriti $u$ useljenike, održivost useljavanja u Hrvatsku nije zajamčena, pa se termin »strani radnici« može zamijeniti uvriježenom sintagmom iz vremena SFRJ, kada su radnici bili »na privremenom radu«, no ovoga puta u Hrvatskoj. 
Tablica 15. Tip smještaja stranih radnika u Hrvatskoj

Table 15. Accomodation of foreign workers in Croatia

\begin{tabular}{lcc}
\hline & $\mathbf{N}$ & $\mathbf{\%}$ \\
\hline Kod rodbine ili prijatelja & 3 & 6,1 \\
\hline Kao podstanar & 46 & 93,9 \\
\hline Ukupno & $\mathbf{4 9}$ & $\mathbf{1 0 0 , 0}$ \\
\hline Osigurao poslodavac & 51 & 86,4 \\
\hline Samostalno & 8 & 13,6 \\
\hline Ukupno & $\mathbf{5 9}$ & $\mathbf{1 0 0 , 0}$ \\
\hline
\end{tabular}

Uz tip i troškove smještaja ispitano je i nekoliko aspekata uvjeta stanovanja, koji se ponekad uvrštavaju u dimenzije socijalne isključenosti, odnosno siromaštva (Siromaštvo, nezaposlenost $i$ socijalna isključenost, 2006: 13). Tako se iz tablice 16 vidi da samo jedan ispitanik ima vlastitu spavaonicu koju ne dijeli s drugim osobama, dok ostali žive u dvokrevetnim ili trokrevetnim sobama, a nekolicina čak i u uvjetima gdje prostor dijele $\mathrm{s}$ još tri ili četiri radnika. Takvi uvjeti stanovanja, najčešće u organizaciji poslodavca, dokidaju privatnost u prostoru stanovanja i onemogućuju eventualne posjete obitelji.

Tablica 16. Broj drugih osoba u spavaonici

Table 16. Number of other persons in the bedroom

\begin{tabular}{ccc}
\hline & $\mathbf{N}$ & $\%$ \\
\hline 0 & 1 & 1,8 \\
\hline 1 & 31 & 54,4 \\
\hline 2 & 19 & 33,3 \\
\hline 3 & 3 & 5,3 \\
\hline 4 & 3 & 5,3 \\
\hline Ukupno & $\mathbf{5 7}$ & $\mathbf{1 0 0 , 0}$ \\
\hline
\end{tabular}

Istraživanjem je utvrđeno da svi ispitanici imaju na raspolaganju kupaonicu, a gotovo svi i kuhinju. Deset ispitanika živi u vlažnim prostorima, 
što upućuje na nižu kvalitetu stambenog prostora, sa zdravstvenim posljedicama.

Uz gore prikazane materijalne uvjete života stranih radnika ispitan je i njihov subjektivni dojam kvalitete života i vlastitoga zdravstvenog stanja. Može se primijetiti kako je zadovoljstvo životom u Hrvatskoj (tablica 17) prilično visoko, jer je oko četvrtine ispitanika procijenilo svoje zadovoljstvo vrijednošću 3, dok ih je dvije trećine zadovoljno ili vrlo zadovoljno. Nijedan ispitanik nije potpuno nezadovoljan, a tek je pet ispitanika samo zadovoljno svojim životom u Hrvatskoj.

Tablica 17. Zadovoljstvo kvalitetom vlastitog života u Hrvatskoj Able 17. Satisfaction with the quality of their lives in Croatia

\begin{tabular}{lcc}
\hline & N & \% \\
\hline Potpuno nezadovoljan / Nezadovoljan & 5 & 8,2 \\
\hline Ni zadovoljan ni nezadovoljan & 16 & 26,2 \\
\hline Zadovoljan & 21 & 34,4 \\
\hline Vrlo zadovoljan & 19 & 31,1 \\
\hline Ukupno & $\mathbf{6 1}$ & $\mathbf{1 0 0 , 0}$ \\
\hline
\end{tabular}

Završna dimenzija ispitivanja kvalitete života obuhvaćala je ispitivanje samoprocjene zdravstvenog stanja ispitanika (tablica 18). Većina ih svoje zdravlje procjenjuje jako dobrim, a skoro četvrtina vrlo dobrim. Premda nijedan ispitanik ne procjenjuje svoje stanje jako lošim ili lošim, sedam ispitanika smatra vlastito zdravlje tek osrednjim.

Tablica 18. Samoprocjena zdravstvenog stanja

Table 18. Self-assessment of health status

\begin{tabular}{lcc}
\hline & $\mathbf{N}$ & $\mathbf{\%}$ \\
\hline Jako loše / Loše / Osrednje & 7 & 11,5 \\
\hline Dobro & 13 & 21,3 \\
\hline Jako dobro & 41 & 67,2 \\
\hline Ukupno & $\mathbf{6 1}$ & $\mathbf{1 0 0 , 0}$ \\
\hline
\end{tabular}




\section{Socijalna isključenost i diskriminacija}

Dimenzije koje se prikazuju u ovom poglavlju mjerene su putem članstva u sindikatima i civilnim udrugama, samoprocjenom pripadnosti društvu te osjećajima izoliranosti, sigurnosti i osamljenosti. Zbog toga je u istraživanju socijalne isključenosti važno utvrditi broj, vrstu i kvalitetu poznanstava i veza koje strani radnici imaju u Hrvatskoj. Tako se iz tablice 19 saznaje da ispitanici uglavnom nisu članovi sindikata. No zanimljivo je primijetiti da je učestalost članstva u sindikatu gotovo ista u Hrvatskoj kao i u zemlji porijekla.

Tablica 19. Članstvo u sindikatu

Table 19. Union membership

\begin{tabular}{|c|c|c|c|c|c|}
\hline & \multicolumn{2}{|c|}{ NE } & \multicolumn{2}{|c|}{ DA } & \multirow{2}{*}{$\begin{array}{c}\text { Ukupno } \\
\mathbf{N}\end{array}$} \\
\hline & $\mathbf{N}$ & $\%$ & $\mathbf{N}$ & $\%$ & \\
\hline Jeste li član sindikata? & 54 & 88,5 & 7 & 11,5 & 61 \\
\hline $\begin{array}{l}\text { Jeste li bili član sindikata u } \\
\text { zemlji svoga porijekla? }\end{array}$ & 53 & 88,3 & 7 & 11,7 & 60 \\
\hline
\end{tabular}

Za razliku od sindikata članstvo u udrugama bilježi stanoviti pad s dolaskom u Hrvatsku, što se može objasniti intenzivnim načinom rada, pa čak ni oni koji bi željeli sudjelovati u radu udruga ili klubova nemaju za to vremena.

Tablica 20. Članstvo u udrugama

Table 20. Membership in associations

\begin{tabular}{|c|c|c|c|c|c|}
\hline & \multicolumn{2}{|c|}{$\mathrm{NE}$} & \multicolumn{2}{|c|}{ DA } & \multirow{2}{*}{$\begin{array}{c}\text { Ukupno } \\
\mathbf{N}\end{array}$} \\
\hline & $\mathbf{N}$ & $\%$ & $\mathbf{N}$ & $\%$ & \\
\hline $\begin{array}{l}\text { Jeste li član neke udruge, kulturno- } \\
\text { umjetničkog društva, sportskoga } \\
\text { kluba i slično? }\end{array}$ & 56 & 91,8 & 5 & 8,2 & 61 \\
\hline $\begin{array}{l}\text { Jeste li član neke druge organizacije } \\
\text { (udruge, društva, stranke) u zemlji } \\
\text { svoga porijekla? }\end{array}$ & 52 & 85,3 & 9 & 14,7 & 61 \\
\hline
\end{tabular}


U istraživanju D., Maslić Seršić, Z., Galić, i B., Šverko (2006) socijalna je izolacija mjerena pitanjem »Smatrate li se sastavnim i korisnim članom društvene zajednice? «Za potrebe ovog istraživanja to je pitanje podijeljeno na dva kako bi se provjerilo je li riječ o odvojenim poimanjima. Prema rezultatima, iako se može primijetiti određena razlika - točnije, osjećaj ispitanika da su sastavni dio društva nešto je izraženiji od onoga da su korisni članovi - odgovori pokazuju doista visoku podudarnost, što govori da je osjećaj socijalne izoliranosti među ispitanicima vrlo nizak (tablica 21). Slične raspodjele dobivene su u i odgovorima na pitanja osjećaju li se prihvaćeno u hrvatskom društvu i na radnome mjestu te osjećaju li se sigurno. Točnije, ti su odgovori još nagnutiji prema višim vrijednostima. Na temelju svih tih pokazatelja možemo zaključiti da je samoprocjena socijalne isključenosti stranih radnika u Hrvatskoj vrlo niska i da prevladava osjećaj sigurnosti, prihvaćenosti i integriranosti u hrvatsko društvo.

Budući da strani radnici u Hrvatskoj najveći broj socijalnih odnosa grade na radnome mjestu, osjećaj prihvaćenosti pod velikim je utjecajem radnih odnosa na poslu. Podatak o osjećaju prihvaćenosti međutim potvrđuje vjerojatno i vrlo niske socijalne aspiracije ispitanika, koji većinom pokazuju zadovoljstvo kvalitetom života u Hrvatskoj, usprkos kolektivnom stanovanju i skromnim prihodima. U hrvatskoj javnosti strani radnici još uvijek uglavnom nisu percipirani kao velika konkurentska grupa na tržištu rada, no lako je moguće da će s dužim boravkom te većom integracijom na tržištu stanovanja i rada, kao i jačanjem konkurencije s hrvatskim radnicima, osjećaj integriranosti opadati. To potvrđuju i podaci dosadašnjih istraživanja stavova prema migrantima u Hrvatskoj, prema kojima hrvatski ispitanici prosječno u velikoj mjeri pokazuju nesklonost prema, makar samo i mogućemu, uključivanju stranih radnika u hrvatsko društvo (Čačić-Kumpes, Gregurović i Kumpes, 2012: 322). Zasad međutim subjektivni osjećaj upućuje na zaključak da strani radnici u Hrvatskoj ne doživljavaju kolektivnu socijalnu isključenost. 
Tablica 21. Socijalna izolacija i sigurnost (\%)

Table 21. Social isolation and security (\%)

\begin{tabular}{lccccc}
\hline & $\begin{array}{c}\text { Uopće } \\
\text { ne }\end{array}$ & $\begin{array}{c}\text { Uglavnom } \\
\text { ne }\end{array}$ & $\begin{array}{c}\text { Ni da ni } \\
\text { ne }\end{array}$ & $\begin{array}{c}\text { Uglavnom } \\
\text { da }\end{array}$ & $\begin{array}{c}\text { Da, u } \\
\text { potpunosti }\end{array}$ \\
\hline $\begin{array}{l}\text { Osjećate li se sigurno } \\
\text { u Hrvatskoj? }\end{array}$ & - & - & 1,64 & 39,34 & 59,02 \\
\hline $\begin{array}{l}\text { Osjećate li se } \\
\text { prihvaćeno u } \\
\text { hrvatskom društvu? }\end{array}$ & - & 1,64 & - & 45,90 & 52,46 \\
\hline $\begin{array}{l}\text { Osjećate li se } \\
\text { prihvaćeno na svome } \\
\text { radnome mjestu? }\end{array}$ & - & - & 3,33 & 40,00 & 56,67 \\
\hline $\begin{array}{l}\text { Imate li osjećaj da } \\
\text { ste sastavni dio } \\
\text { hrvatskog društva? }\end{array}$ & - & 1,67 & 8,33 & 53,33 & 36,67 \\
\hline $\begin{array}{l}\text { Imate li osjećaj da } \\
\text { ste koristan član } \\
\text { hrvatskog društva? }\end{array}$ & - & 1,64 & 6,56 & 52,46 & 39,34 \\
\hline
\end{tabular}

Kao dodatni pokazatelj socijalne izolacije, odnosno isključenosti (Šućur, 2004), ispitan je i osjećaj osamljenosti, koji prema rezultatima istraživanja kod ispitanika nije izražen. Naime polovina ispitanika tvrdi da se gotovo nikada ne osjeća osamljeno (tablica 22). Ipak, četvrtina ih je odabrala srednju kategoriju, a njih pet reklo je da se gotovo stalno osjeća osamljeno, što ipak daje nešto lošiju sliku nego gore prikazani indikatori. Pritom valja imati na umu da je osjećaj osamljenosti u većoj mjeri uvjetovan različitim čimbenicima, od vlastitoga društvenog statusa i osjećaja integracije u hrvatsko društvo do trenutačnih odnosa s obitelji i prijateljima. Osim toga suvremeni i jeftini oblici komunikacije omogućuju česte kontakte s obitelji i prijateljima u zemlji porijekla, a česta putovanja također najvjerojatnije utječu na ublažavanje osjećaja osamljenosti i izolacije. 
Tablica 22. Osjećaj osamljenosti

Table 22. Feeling of loneliness

\begin{tabular}{lcc}
\hline & N & \% \\
\hline Gotovo nikada & 31 & 50,8 \\
\hline Jako rijetko & 5 & 8,2 \\
\hline Ponekad & 16 & 26,2 \\
\hline Često & 4 & 6,6 \\
\hline Gotovo stalno & 5 & 8,2 \\
\hline Ukupno & $\mathbf{6 1}$ & $\mathbf{1 0 0 , 0}$ \\
\hline
\end{tabular}

Uz gore prikazane samoprocjene socijalna izolacija ispitivana je i dvama dodatnim objektivnim pokazateljima: veličinom poznaničkih mreža i učestalošću socijalnih kontakata. Pokušalo se utvrditi u kolikoj mjeri te mreže i kontakti uključuju domaće, hrvatsko stanovništvo, što se može smatrati približnim pokazateljem premošćujuće ili povezujuće naravi socijalnoga kapitala stranih radnika (Woolcock i Narayan, 2000).

Iz tablica 23 i 24 prije svega se može primijetiti kako su svi ispitanici rekli da imaju poznanike i na radnome mjestu i izvan njega. Tek njih pet nije navelo nikakva poznanstva nevezana uz radno mjesto. U oba slučaja većina ih ima do dvadeset poznanika, što je uobičajeno kod takvih samoprocjena. No za poznanstva izvan radnog mjesta čak $62,5 \%$ navelo je manje od deset poznanika, što govori da su poznaničke mreže koje su ispitanici uspostavili u Hrvatskoj ipak donekle manjeg opsega. Brojnost i kvaliteta tih mreža nesumnjivo se odražavaju i na kvalitetu socijalne potpore koju mogu iz njih očekivati i primiti. 
Tablica 23. Broj poznanika na poslu

Table 23. Number of acquaintances at work

\begin{tabular}{lll}
\hline & $\mathbf{N}$ & $\mathbf{\%}$ \\
\hline $1-10$ & 23 & 37,7 \\
\hline $11-20$ & 13 & 21,3 \\
\hline $21-30$ & 9 & 14,8 \\
\hline $31-40$ & 5 & 8,2 \\
\hline $41-50$ & 11 & 18,0 \\
\hline Ukupno & $\mathbf{6 1}$ & $\mathbf{1 0 0 , 0}$ \\
\hline AS & \multicolumn{2}{c}{21,7} \\
\hline SD & 15,34 \\
\hline medijan & 20 \\
\hline mod & 10 \\
\hline
\end{tabular}

Tablica 24: Broj poznanika izvan posla

Table 24. Number of acquaintances outside work

\begin{tabular}{lll}
\hline & $\mathbf{N}$ & $\mathbf{\%}$ \\
\hline $1-10$ & 35 & 62,5 \\
\hline $11-20$ & 9 & 16,1 \\
\hline $21-30$ & 1 & 1,8 \\
\hline $41-50$ & 11 & 19,6 \\
\hline Ukupno & $\mathbf{5 6}$ & $\mathbf{1 0 0 , 0}$ \\
\hline AS & & 11,5 \\
\hline SD & 11,4 \\
\hline medijan & 10 \\
\hline mod & & 10 \\
\hline
\end{tabular}

Kako gotovo svi ispitanici rade, između ostaloga, s drugim ljudima iz svoje zemlje porijekla (tablica 25), očekivano je da gotovo svi imaju druge migrante među poznanicima na radnome mjestu. 
Tablica 25. Prisutnost drugih stranih radnika u tvrtki

Table 25. Presence of other foreign workers in the firm

\begin{tabular}{|c|c|c|c|c|c|}
\hline & \multicolumn{2}{|c|}{ NE } & \multicolumn{2}{|c|}{ DA } & \multirow{2}{*}{$\begin{array}{l}\text { Ukupno } \\
\mathbf{N}\end{array}$} \\
\hline & $\mathbf{N}$ & $\%$ & $\mathbf{N}$ & $\%$ & \\
\hline $\begin{array}{l}\text { Radi li još ljudi iz zemlje vašeg } \\
\text { porijekla s Vama? }\end{array}$ & 3 & 4,9 & 58 & 95,1 & 61 \\
\hline $\begin{array}{l}\text { Rade li i ljudi iz trećih zemalja s } \\
\text { Vama? }\end{array}$ & 54 & 88,5 & 7 & 11,5 & 61 \\
\hline
\end{tabular}

Više od $40 \%$ ispitanika postavilo je omjer hrvatskih i stranih poznanika na točno $50: 50$, tj. naveli su da imaju jednaki broj drugih migranata i hrvatskih državljana među poznanicima na poslu.

Tablica 26. Udio državljana Republike Hrvatske među poznanicima na poslu

Table 26. The share of Croatian citizens among acquaintances at work

\begin{tabular}{lcc}
\hline & $\mathbf{N}$ & $\mathbf{\%}$ \\
\hline $0 \%-25 \%$ & 4 & 6,7 \\
\hline $25,01 \%-50 \%$ & 32 & 53,3 \\
\hline $50,01 \%-75 \%$ & 13 & 21,7 \\
\hline $75,01 \%-100 \%$ & 11 & 18,3 \\
\hline Ukupno & $\mathbf{6 0}$ & $\mathbf{1 0 0 , 0}$ \\
\hline
\end{tabular}

Među poznanstvima izvan radnog mjesta (tablica 27) znatno su učestalije poznaničke mreže koje uključuju manji udio drugih migranata. Valja dodati i da je, u negrupiranim podacima, najveći broj ispitanika (gotovo pedeset posto) naveo kako su njihovi poznanici izvan radnog mjesta isključivo hrvatski državljani. 
Tablica 27. Udio državljana Republike Hrvatske među poznanicima izvan radnog mjesta

Table 27. The share of Croatian citizens among acquaintances outside work

\begin{tabular}{ccc}
\hline $\begin{array}{c}\text { Broj poznanika izvan radnog mjesta koji } \\
\text { su državljani RH }\end{array}$ & N & \% \\
\hline $0-25$ & 1 & 2,2 \\
\hline $25,01-50$ & 11 & 23,9 \\
\hline $50,01-75$ & 6 & 13,0 \\
\hline $75,01-100$ & 28 & 60,9 \\
\hline Ukupno & $\mathbf{4 6}$ & $\mathbf{1 0 0 , 0}$ \\
\hline
\end{tabular}

Rezultati iz tablice 28 pokazuju da su gotovo svi ispitanici u jednom trenutku bili izloženi nekom obliku diskriminacije. Zanimljivo je da, uz iznimku odgovora trojice ispitanika na prvo pitanje, svi ostali kažu kako im se to dogodilo samo jednom. Uzme li se u obzir zastupljenost iskustva nekog oblika diskriminacije među gotovo svim ispitanicima, može se pretpostaviti da su barem neki oblici diskriminacije stranih radnika u svakodnevici rasprostranjeni. No upitani jesu li imali ikakve druge neugodnosti zbog toga što su stranci, svi ispitanici odgovorili su niječno.

Tablica 28. Iskustvo diskriminacije

Table 28. Experience of discrimination

\begin{tabular}{|c|c|c|c|c|c|c|c|}
\hline & \multicolumn{2}{|c|}{ NE } & \multicolumn{2}{|c|}{$\begin{array}{c}\text { DA, } \\
\text { jednom }\end{array}$} & \multicolumn{2}{|c|}{$\begin{array}{c}\text { DA, više } \\
\text { puta }\end{array}$} & \multirow{2}{*}{$\begin{array}{c}\text { Ukupno } \\
\mathbf{N}\end{array}$} \\
\hline & $\mathbf{N}$ & $\%$ & $\mathbf{N}$ & $\%$ & $\mathbf{N}$ & $\%$ & \\
\hline $\begin{array}{l}\text { Nazivali su me pogrdnim } \\
\text { imenima na radnome mjestu } \\
\text { jer sam stranac }\end{array}$ & 1 & 1,6 & 57 & 93,5 & 3 & 4,9 & 61 \\
\hline $\begin{array}{l}\text { Nazivali su me pogrdnim } \\
\text { imenima na ulici, u dućanu, } \\
\text { kafiću i sl. jer sam stranac }\end{array}$ & 1 & 1,6 & 60 & 98,4 & - & - & 61 \\
\hline $\begin{array}{l}\text { Odbili su me poslužiti u } \\
\text { kafiću, restoranu i sl. jer sam } \\
\text { stranac }\end{array}$ & 1 & 1,6 & 60 & 98,4 & - & - & 61 \\
\hline
\end{tabular}




\begin{tabular}{|c|c|c|c|c|c|c|c|}
\hline & \multicolumn{2}{|c|}{$\mathrm{NE}$} & \multicolumn{2}{|c|}{$\begin{array}{c}\text { DA, } \\
\text { jednom }\end{array}$} & \multicolumn{2}{|c|}{$\begin{array}{l}\text { DA, više } \\
\text { puta }\end{array}$} & \multirow{2}{*}{$\begin{array}{c}\text { Ukupno } \\
\mathbf{N}\end{array}$} \\
\hline & $\mathbf{N}$ & $\%$ & $\mathbf{N}$ & $\%$ & $\mathbf{N}$ & $\%$ & \\
\hline $\begin{array}{l}\text { Odbili su me uslužiti u pošti, } \\
\text { banci i sl. jer sam stranac }\end{array}$ & 2 & 3,3 & 59 & 96,7 & - & - & 61 \\
\hline
\end{tabular}

Uz te relativno blaže oblike diskriminacije istraživanjem se utvrdilo jesu li ispitanici bili izloženi i nasilju (na radnome mjestu ili na ulici, u kafiću i slično). Samo je jedan ispitanik rekao da je jednom bio fizički napadnut na radnome mjestu. Blaži oblici diskriminacije široko su rasprostranjeni, dok su teži oblici manje prisutni, vjerojatno zato što odnosi između stranih radnika i pripadnika domaće populacije nisu prerasli $u$ grupne odnose, $t j$. grupne sukobe unutar kojih se svaki kulturni i socijalni atribut pojedinca prepoznaje kao marker između grupa i postaje okidač za različite oblike sukoba uključujući i fizičko nasilje.

\section{Transnacionalne veze}

Prema rezultatima istraživanja koji su navedeni u tablici 29, svi ispitanici imaju članove obitelji u zemlji porijekla, a gotovo svi tamo imaju i dobre prijatelje. Osim toga čak osamdeset posto njih ima i članove obitelji te dobre prijatelje u trećim, stranim zemljama. Među tim trećim zemljama prevladavaju Slovenija, Austrija i Njemačka, a u manjoj mjeri Švicarska, Švedska i Sjedinjene Američke Države. Svaku preostalu zemlju spomenulo je manje od deset posto ispitanika ${ }^{12}$. Ti su podaci u skladu s odabirom odredišta i pravcima emigracije bošnjačkih migranata još od šezdesetih godina 20. stoljeća te donekle i tijekom prisilnih migracija devedesetih. Ne začuđuje dakle podatak da i (većinom bošnjački) radnici u Hrvatskoj navode prijatelje i rođake u tim zemljama. Uzimajući u obzir da prema prijašnjim istraživanjima veliki broj stranih radnika nema prijatelje i rođake samo u zemlji porijekla već i u brojnim drugim zemljama (Kuti, Gregurović i Božić, 2013), vrlo je vjerojatno da se u slučaju suvremenih radnih migranata u Hrvatskoj ponavljaju obrasci transnacionalnih veza i društvenih prostora koji se pronalaze u svim imigracijskim društvima. Na to upućuju i dosadašnja istraživanja transnacionalnih socijalnih prostora koja su uključivala Bošnjake u Hrvatskoj (Božić i Kuti, 2012), a koja pokazuju da su transnacionalne veze preko

12 Riječ je o Australiji, Italiji, Crnoj Gori, Finskoj, Kanadi, Kataru, Rumunjskoj, Nizozemskoj, Velikoj Britaniji, Francuskoj, Danskoj, Ukrajini te Bosni i Hercegovini. 
granica Bosne i Hercegovine izuzetno razvijene te uključuju migrante na gotovo svim kontinentima.

Migracija odavno nije samo jedinstveni i neponovljivi čin preseljenja i fokusiranja svih područja života u novo odredište nego uključuje i očuvanje starih veza i intenzivnu socijalnu razmjenu u nekoliko, često prostorno jako udaljenih lokacija. Katkad su spomenute veze i razmjene toliko jake da odnosi i događaji u udaljenim lokacijama određuju planove i djelovanja migranata i obratno. Tada se već može govoriti o saturiranim transnacionalnim socijalnim prostorima koji se prostiru i preko granica nekoliko nacijadržava (Faist, 2000; Pries, 2001, 2008; Kuti, 2012). Kako su strani radnici u Hrvatskoj većinom novi imigranti vezani uz obitelji u Bosni i Hercegovini, a imaju prijatelje i rođake $u$ drugim europskim zemljama, vrlo je vjerojatno da $\mathrm{i}$ oni, ili barem određeni broj njih, razvijaju transnacionalne veze.

Tablica 29. Transnacionalne veze

Table 29. Transnational ties

\begin{tabular}{|c|c|c|c|c|c|}
\hline & \multicolumn{2}{|c|}{ NE } & \multicolumn{2}{|c|}{ DA } & \multirow{2}{*}{ Ukupno $\mathbf{N}$} \\
\hline & $\mathbf{N}$ & $\%$ & $\mathbf{N}$ & $\%$ & \\
\hline $\begin{array}{l}\text { Imate li članove obitelji koji } \\
\text { žive u zemlji iz koje ste došli? }\end{array}$ & 0 & 0 & 60 & 100 & 60 \\
\hline $\begin{array}{l}\text { Imate li dobre prijatelje koji } \\
\text { žive u zemlji iz koje ste došli? }\end{array}$ & 2 & 3,3 & 59 & 96,7 & 61 \\
\hline $\begin{array}{l}\text { Imate li članove obitelji u } \\
\text { nekim drugim zemljama? }\end{array}$ & 12 & 19,7 & 49 & 80,3 & 61 \\
\hline $\begin{array}{l}\text { Imate li dobre prijatelje } \\
\text { koji žive u nekim drugim } \\
\text { zemljama? }\end{array}$ & 12 & 20 & 48 & 80 & 60 \\
\hline
\end{tabular}

Ispitanici koji su sudjelovali u istraživanju vrlo često putuju u zemlju svoga porijekla. Naime više od polovine njih kući odlazi gotovo svaki tjedan (tablica 30). No tek manji dio ugošćuje rodbinu ili prijatelje; najveći dio čini to tek jednom godišnje. Taj obrazac mobilnosti tipičan je za početne faze migracije, kada muškarci bez obitelji rade kao »radnici gosti« te nakon učvršćenja svoje pozicije u zemlji useljenja počinju pripremnu fazu za useljenje ostalih članova obitelji. Dotad su uglavnom oni mobilni članovi obitelji koji vrlo često posjećuju zemlju porijekla, pod uvjetom da je dostupna 
jeftinijim prijevoznim sredstvima. $U$ toj se fazi migracije strani radnici često udružuju u zajedničkom prijevozu osobnim vozilom do zemlje porijekla. Osim toga kako uvjeti stanovanja stranih radnika ne omogućuju ugošćivanje prijatelja i članova obitelji jer sobu često dijele s drugim radnicima, a i visina njihovih prihoda ne dopušta česta putovanja cijele obitelji, mnogo su pristupačnija samostalna putovanja stranih radnika jednom tjedno u mjesto porijekla nego organiziranje i plaćanje dolaska cijele obitelji.

Tablica 30. Odlasci u zemlju porijekla i posjeti obitelji stranih radnika u Hrvatskoj

Table 30. Going to the country of origin and family visits of foreign workers in Croatia

\begin{tabular}{lccccc}
\hline & Nikada & $\begin{array}{c}\text { Jednom } \\
\text { godišnje }\end{array}$ & $\begin{array}{c}\text { Nekoliko } \\
\text { puta } \\
\text { godišnje }\end{array}$ & $\begin{array}{c}\text { Gotovo } \\
\text { svaki } \\
\text { mjesec }\end{array}$ & $\begin{array}{c}\text { Gotovo } \\
\text { svaki } \\
\text { vikend }\end{array}$ \\
\hline $\begin{array}{l}\text { Putujete li u zemlju iz } \\
\text { koje ste došli? }\end{array}$ & - & $1,67 \%$ & $5,00 \%$ & $38,33 \%$ & $55,00 \%$ \\
\hline $\begin{array}{l}\text { Dolaze li članovi } \\
\text { obitelji, rođaci ili } \\
\text { prijatelji Vama u } \\
\text { posjet? }\end{array}$ & $73,33 \%$ & $16,67 \%$ & $6,67 \%$ & $3,33 \%$ & - \\
\hline
\end{tabular}

Telefonski kontakti iznimno su česti kod velike većine ispitanika te ih se ukupno $85 \%$ čuje s rodbinom i prijateljima gotovo svaki dan ili nekoliko puta tjedno. Učestalost kontakata smanjuje osjećaj izoliranosti i omogućuje uobičajeno funkcioniranje obitelji u kojoj otac, hranitelj, punopravno sudjeluje u životu obitelji.

Većina ispitanika, njih 54, šalje novac obitelji, rodbini ili prijateljima, dok pet ispitanika to ne čini. Iznosi se kreću od 400 do 6.000,00 HRK, iako ih najviše šalje između 2.000,00 i 2.500,00 HRK (tablica 31). 
Tablica 31. Mjesečni iznos novca koji se šalje obitelji

Table 31. Montly amount of money to be sent to the family

\begin{tabular}{lcc}
\hline & N & \% \\
\hline 400,00 HRK & 1 & 2,0 \\
\hline 500,00 HRK & 1 & 2,0 \\
\hline $1.000,00$ HRK & 6 & 12,0 \\
\hline $1.400,00$ HRK & 1 & 2,0 \\
\hline $1.500,00$ HRK & 7 & 14,0 \\
\hline $1.800,00$ HRK & 2 & 4,0 \\
\hline $2.000,00$ HRK & 15 & 30,0 \\
\hline $2.400,00$ HRK & 1 & 2,0 \\
\hline $2.500,00$ HRK & 10 & 20,0 \\
\hline $3.000,00$ HRK & 3 & 6,0 \\
\hline $4.000,00$ HRK & 2 & 4,0 \\
\hline $6.000,00$ HRK & 1 & 2,0 \\
\hline Ukupno & 50 & $\mathbf{1 0 0 , 0}$ \\
\hline
\end{tabular}

Indikativniji su podaci koji iskazuju tu svotu kao dio u ukupnome mjesečnom prihodu ispitanika. Najveći dio njih šalje nešto više od polovine svoga prihoda, a 33\% između četvrtine i polovine, što govori da se velika većina ispitanika odriče većeg dijela prihoda kako bi pomogla bliskim osobama, odnosno najužoj obitelji u zemlji svoga porijekla. Ti indikatori upućuju na zaključak da strani radnici u Hrvatskoj razvijaju snažne transnacionalne veze i održavaju transnacionalne obitelji. Koriste se fizičkom mobilnošću i radom u Hrvatskoj kako bi ekonomski održali obitelj, pri čemu upotrebljavaju suvremene i sada jeftine oblike komunikacije kako bi održali koheziju vlastite, transnacionalne obitelji.

\section{Planovi za ostanak u Hrvatskoj}

Tek manji dio ispitanika, njih sedam, ne namjerava ostati u Republici Hrvatskoj, od kojih se petorica planiraju vratiti u zemlju porijekla. Preostala dvojica ispitanika planiraju otići u neku drugu zemlju u kojoj imaju obitelj ili prijatelje. Među onima koji planiraju ostati najveći dio želi ostati trajno 
(tablica 32), pa se njih $44 \%$ odlučilo za odgovor »zauvijek «, a $32 \%$ za odgovor »što je dulje moguće«. Nakon što se tome pribroji daljnjih $14 \%$ koji planiraju ostati do mirovine, može se zaključiti da tek vrlo mali broj ispitanika vidi svoju radnu migraciju u Hrvatsku kao nešto privremeno.

Tablica 32. Planirana duljina ostanka

Table 32. Planned length of stay

\begin{tabular}{lcc}
\hline & N & $\%$ \\
\hline Dok Hrvatska ne uđe u EU & 1 & 2,0 \\
\hline Do mirovine & 7 & 14,0 \\
\hline Što je duže moguće & 16 & 32,0 \\
\hline Zauvijek & 22 & 44,0 \\
\hline Nešto drugo & 4 & 8,0 \\
\hline Ukupno & $\mathbf{5 0}$ & $\mathbf{1 0 0 , 0}$ \\
\hline
\end{tabular}

Oko trećine ispitanika planira dovesti obitelj u Hrvatsku, što otprilike odgovara broju onih koji planiraju ostati u Hrvatskoj zauvijek. No kako je utvrđeno da ipak velika većina ispitanika namjerava duže ostati u Hrvatskoj, čini se da ih tek trećina (ili nešto više, jer manji dio nije u braku i/ili nema djecu) planira trajno se nastaniti ovdje s obiteljima. Prema podacima iz tablice 33, čini se da je najveća zapreka u dovođenju obitelji neposjedovanje hrvatskog državljanstava, odnosno neriješeni pravni i ekonomski status.

Tablica 33. Planirano vrijeme dovođenja obitelji

Table 33. Planned time for bringing the family

\begin{tabular}{lcc}
\hline & $\mathbf{N}$ & $\mathbf{\%}$ \\
\hline Što je prije moguće & 1 & 4,8 \\
\hline Kada riješim svoj pravni i ekonomski status ovdje & 7 & 33,3 \\
\hline Kada dobijem hrvatsko državljanstvo & 12 & 57,1 \\
\hline Kad Hrvatska uđe u EU & 1 & 4,8 \\
\hline Ukupno & $\mathbf{2 1}$ & $\mathbf{1 0 0 , 0}$ \\
\hline
\end{tabular}


Zaključno razmatrajući planove vezane uz ostanak stranih radnika u Hrvatskoj ili njihov odlazak iz nje, zanimljivo je da se oni, usprkos brojnim rođačkim i prijateljskim vezama u zemljama Europske unije, svojim boravkom u Hrvatskoj ne koriste kao odskočnom daskom za daljnju migraciju prema Europskoj uniji. Naime planiraju ili povratak u zemlju porijekla ili ostanak u Hrvatskoj, što pokazuje da radna migracija prema Hrvatskoj nije dio širega migracijskog sustava, već najčešće oblik strategije preživljavanja populacije s niskim ekonomskim i kulturnim kapitalom, prije svega iz susjedne Bosne i Hercegovine.

\section{ZAKLJUČAK}

Usprkos velikim ograničenjima ovog istraživanja, posebice nedostatnim resursima da bi se nadišla ograničenja prigodnog uzorka te njegov eksplorativni karakter, istraživanje je utvrdilo osnovne demografske karakteristike stranih radnika, njihovo geografsko porijeklo, način i razloge dolaska te osnovne trendove u pogledu njihove socijalne isključenosti i diskriminacije, kao i trajnosti migracijskog procesa. Usto su dobiveni uvidi u društvene veze i kontakte stranih radnika u Hrvatskoj, kontakte s rođacima i prijateljima u drugim zemljama te životne planove i orijentaciju imigranata.

Dobiveni podaci pokazuju da su među stranim radnicima najzastupljeniji hranitelji obitelji koji doznakama uzdržavaju svoje obitelji. Takva obiteljska raspodjela slijedi koncept tzv. muškoga hranitelja (engl. male breadwinner model), prema kojemu muškarci zarađuju obiteljski dohodak kojim se financijski skrbe za obitelj. Nadalje, riječ je o relativno slabije obrazovanoj populaciji u usporedbi s ukupnom populacijom Hrvatske, ali i Bosne i Hercegovine, iz koje najčešće dolaze. No gledajući ukupnu populaciju stranih radnika, riječ je o obrazovanim radnicima koji su ili stručno obrazovani za posao koji obavljaju ili obavljaju posao ispod razine obrazovanja. Ispitanici su gradskog i prigradskog porijekla (ukupno $71,7 \%$ uzorka), ali zamjetni broj njih, oko trećine uzorka (28\%), dolazi sa sela. Dominantna zemlja porijekla, Bosna i Hercegovina, odnosno njezina geografska, jezična i kulturna blizina Hrvatskoj, najvjerojatnije je u izravnoj vezi s prezastupljenošću stranih radnika tog porijekla. Ispitanici su kao najvažnije razloge dolaska u najvećem broju isticali bolje uvjete rada, veću mogućnost zarade i nemogućnost pronalaska posla u vlastitoj zemlji te $u$ nešto manjoj mjeri geografsku blizinu i relativnu lakoću dobivanja radne dozvole. Čini se da se Hrvatska još uvijek nudi kao dobro odredište za nezaposlene kvalificirane bosanske radnike koji nemaju hrvatsko državljanstvo, koji već imaju obitelji, a ne- 
maju mogućnost za zapošljavanje u trećim zemljama s višim plaćama i boljim uvjetima života i rada. Prosječna primanja istraživanih stranih radnika izrazito su niža od hrvatskoga prosjeka, a samo trinaest posto ispitanika ima plaću koja je blizu ili iznad hrvatskoga prosjeka. Iz dobivenih podataka uočava se ekonomska ugroženost ispitanika, posebice onih s obitelji. Nakon slanja dijela plaće obitelji strani radnici u Hrvatskoj žive ispod praga siromaštva. No subjektivna procjena financijske situacije ispitanika daje pozitivniju sliku od objektivnih pokazatelja.

Na temelju dobivenih podataka možemo zaključiti i da je samoprocjena socijalne isključenosti stranih radnika u Hrvatskoj vrlo niska te da prevladava osjećaj sigurnosti, prihvaćenosti i integriranosti u hrvatsko društvo. Budući da strani radnici u Hrvatskoj najveći broj socijalnih odnosa grade na radnome mjestu, osjećaj prihvaćenosti pod velikim je utjecajem radnih odnosa na poslu. Podatak o osjećaju prihvaćenosti međutim potvrđuje vjerojatno i vrlo niske socijalne aspiracije ispitanika, koji većinom pokazuju zadovoljstvo kvalitetom života u Hrvatskoj, usprkos kolektivnom stanovanju i skromnim prihodima. Blaži oblici diskriminacije široko su rasprostranjeni, dok su teži oblici manje prisutni jer odnosi između stranih radnika i pripadnika domaće populacije nisu prerasli u grupne odnose, tj. grupne sukobe u uvjetima natjecanja na tržištu rada

Podaci nadalje upućuju na zaključak da strani radnici u Hrvatskoj razvijaju snažne transnacionalne veze i održavaju transnacionalne obitelji. Koriste se fizičkom mobilnošću i radom u Hrvatskoj kako bi ekonomski održali obitelj, pri čemu upotrebljavaju suvremene i sada jeftine oblike komunikacije kako bi održali koheziju vlastite, transnacionalne obitelji.

Razmatrajući planove vezane uz ostanak stranih radnika u Hrvatskoj ili odlazak iz nje, može se primijetiti da se strani radnici usprkos brojnim rođačkim i prijateljskim vezama u zemljama Europske unije svojim boravkom u Hrvatskoj ne koriste kao odskočnom daskom za daljnju migraciju prema Europskoj uniji te planiraju ili povratak u zemlju porijekla ili ostanak u Hrvatskoj. Taj podatak vrlo vjerojatno govori da radna migracija prema Hrvatskoj nije dio širega migracijskog sustava, već oblik transnacionalne strategije preživljavanja na »male udaljenosti«, i to populacije s niskim ekonomskim i kulturnim kapitalom, prije svega iz susjedne Bosne i Hercegovine. 


\section{LITERATURA}

Barada, V. (2013). Unutarnje radne migracije mladih žena u Hrvatskoj. Zadar (istraživački materijal, osobna arhiva).

Bhalla, A. i Lapeyre, F. (1995). Social Exclusion Revisited. Towards an Analytical and Operational Famework. Geneva: International Institute for Labour Studies.

Božić, S. i Burić, I. (2005). Migracijski potencijal Hrvatske - mikroanalitički aspekti, Migracijske i etničke teme, 21 (1-2): 9-34.

Božić, S. i Kuti, S. (2012). Kroatien als Immigrationsland: Transnationale soziale Räume der albanischen, bosniakischen und chinesischen Immigranten, u: A. Welebil i J. Nuber (ur.). Gast:arbeit. Gehen - bleiben - zurückkehren. Positionen zur Arbeitsmigration im Raum Ex-Jugoslawien. Wien: Edition Art Science, 245-276.

Crompton, R. (1999). The Decline of Male Breadwinner: Explanations and Interpretations, u: R. Cromptin (ur.). Restructuring Gender Relations and Employment. Decline of the Male Breadwinner. Oxford: Oxford University Press, 1-25.

Čačić-Kumpes, J., Gregurović, S. i Kumpes, J. (2012). Migracija, integracija i stavovi prema imigrantima u Hrvatskoj, Revija za sociologiju, 42 (3): 305-366, doi: 10.5613/ rzs.42.3.3.

Ellingsaeter, A. L. (1999). Dual Breadwinners between State and Market, u: R. Cromptin (ur.). Restructuring Gender Relations and Employment. Decline of the Male Breadwinner. Oxford: Oxford University Press, 40-59.

Faist, T. (2000). Transnationalization in International Migration: Implications for the Study of Citizenship and Culture, Ethnic and Racial Studies, 23 (2): 189-222, doi: 10.1080/014198700329024.

Fassmann, H. i Hinterman, C. (1997). Migrationspotential Ostmitteleuropa: Struktur und Motivation potentieller Migranten aus Polen, der Slowakei, Tschechien und Ungarn. Wien: Verlag der Österreichischen Akademie der Wissenschaften.

Foner, N. (1997). What's New About Transnationalism? New York Immigrants Today and at the Turn of the Century, Diaspora: A Journal of Transnational Studies, 6 (3): 355375, doi: 10.1353/dsp.1997.0013.

Gregurović, S. (2011). Obilježja migracijskih tokova i integracija novih imigrantskih grupa na tržištu rada u južnoeuropskim zemljama članicama Europske unije, Migracijske i etničke teme, 27 (1): 57-75.

Hess, S. (2002). Au Pairs als informalisierte Hausarbeiterinnen - Flexibilisierung und Ethnisierung der Versorgungsarbeiten, u: C. Gather et al. (ur.). Weltmarkt Privathaushalt. Bezahlte Hausarbeit im globalen Wandel. Münster: Westfälisches Dampfboot, 103-119.

Hess, S. i Lenz, R. (2001). Das Comeback der Dienstmädchen. Zwei etnographische Feldstudien in Deutschland und Zypern über die neuen Arbeitgeberinnen im Privathaushalt, u: S. Hessi i R. Lenz (ur.). Geschlecht und Globalisierung: ein kulturwissenschaftlicher Streifzug durch transnationale Räume. Frankfurt am Main: Ulrike Helmer Verlag, 128-165.

Itzigsohn, J. i Giorguli Saucedo, S. (2002). Immigrant Incorporation and Sociocultural Transnationalism, International Migration Review, 36 (3): 766-798.

Kuti, S (2012). Koncepti transnacionalnih socijalnih prostora i polja u istraživanju migracijskih i postmigracijskih procesa, Migracijske i etničke teme, 28 (2): 119-141. 
Kuti, S., Gregurović, S. i Božić, S. (2013). Bošnjaci u Hrvatskoj: useljavanje i transnacionalni socijalni prostori, u: M. Emirhafizović et al. (ur.). Migracije iz BiH. Sarajevo: Institut za društvena istraživanja (IDI) Fakulteta političkih nauka Univerziteta u Sarajevu -Ministarstvo za ljudska prava i izbjeglice $\mathrm{BiH}, 105-113$.

Landolt, P. (2001). Salvadoran Economic Transnationalism: Embedded Strategies for Household Maintenance, Immigrant Incorporation, and Entrepreneurial Expansion, Global Networks, 1 (3): 217-241, doi: 10.1111/1471-0374.00014.

Levitt, P., DeWind, J. i Vertovec S. (2003). International Perspectives on Transnational Migration: An Introduction, International Migration Review, 37 (3): 565-575, doi: 10.1111/j.1747-7379.2003.tb00150.x.

Lutz, H. (2002). Transnationalität im Haushalt, u: C. Gather et al. (ur.). Weltmarkt Privathaushalt: Bezahlte Hausarbeit im globalen Wandel. Münster: Westfälusches Dampfboot, 86-102.

Maslić Seršić, D., Galić, Z. i Šverko, B. (2006). Nezaposlenost i socijalna isključenost: longitudinalna studija, Revija za socijalnu politiku, 13 (1): 1-14, doi: 10.3935/rsp. v13i1.417.

Mazzucato, V. (2010). Operationalising Transnational Migrant Networks through a Simultaneous Matched Sample Methodology, u: R. Bauböck i Th. Faist (ur.). Diaspora and Transnationalism: Concepts, Theories and Methods. Amsterdam: Amsterdam University Press, 205-223.

Mežnarić, S. (1991). Osvajanje prostora - prikrivanje vremena: migracije umjesto razvoja. Zagreb: Sociološko društvo Hrvatske.

Morokvasic, M. (2004). Settled in Mobility: Engendering post-wall Migration in Europe, Feminist Review, 77 (1): 7-25, doi: 10.1057/palgrave.fr.9400154.

Ostroški, Lj. (2011). Hrvatska u brojkama 2011. Zagreb: Državni zavod za statistiku.

Pries, L. (2001). The Approach of Transnational Social Spaces: Responding to New Configurations of the Social and the Spatial, u: L. Pries (ur.). New Transnational Social Spaces. International Migration and Transnational Companies in the Early Twenty-first Century. London: Routledge, 3-33.

Pries, L. (2008). Die Transnationalisierung der sozialen Welt. Frankfurt am Mein: Suhrkamp.

Šućur, Z. (2004). Socijalna isključenost: pojam, pristupi i operacionalizacija, Revija za sociologiju, 35 (1-2): 45-60.

Šućur, Z. (2006). Siromaštvo, višedimenzionalna deprivacija i socijalna isključenost u Hrvatskoj, Revija za sociologiju, 37 (3-4): 131-147.

Siromaštvo, nezaposlenost i socijalna isključenost (2006). Zagreb: UNDP

Woolcock, N. i Narayan, D. (2000). Social capital: Implications for Development Theory, Research, and Policy, The World Bank Observer, 15 (2): 225-249, doi: 10.1093/ wbro/15.2.225.

\section{IZVORI}

Hrvatski zavod za zapošljavanje, http://www.hzz.hr/default.aspx (7. 12. 2013.).

Statistički ljetopis Republike Hrvatske: 2013., Državni zavod za statistiku, Zagreb, http:// www.dzs.hr/Hrv_Eng/ljetopis/2013/sljh2013.pdf (8. 12. 2013.)

Zakon o strancima, Narodne novine, br. 130/2011. 


\title{
Foreign Workers in Croatia: Origin, Status, Orientation
}

\section{Saša Božić, Boško Kuzmanović, Valerija Barada}

\begin{abstract}
Summary
In the public discourse Croatia is primarily seen as a country of emigration rather than immigration but the trends of labour mobility in the past decade indicate that Croatia is no longer only a country of emigration. It is increasingly becoming a country of labour immigration, although the number of (registered) foreign workers is not large. Since there are no data on the origin, status, quality of life and orientations of foreign workers in Croatia, this exploratory research is focused on acquiring the first insights into their social position within Croatian society. The research determined the basic demographic characteristics of foreign workers, their geographical origin, reasons for their immigration, main trends in social exclusion and discrimination, as well as the sustainability of their immigration. In addition, the research gave insights into social ties and contacts of foreign workers within Croatian society, as well as their ties with relatives and friends in other countries. Finally, the life plans and orientation of immigrants were disclosed.
\end{abstract}

KEY WORDS: Croatia, immigrants, labour immigration, social exclusion, quality of life, transnational ties 